\title{
Analisis Depresiasi dan Kebijakan Pengelolaan Sumberdaya Ikan Layang di Wilayah Perairan Kota Ambon
}

Janer Sangadji1 ${ }^{1)}$ Tridoyo Kusumastanto ${ }^{2)}$, Sahat. M. H. Simanjuntak ${ }^{3)}$

\section{INFO NASKAH :}

\section{Proses Naskah:}

Diterimahasilrevisi 10 Maret 2014

Diterimauntukterbit 12 April 2014

Terbit April 2014

Keywords :

Layang Fish Resources, ,

Dynamic Models

Analytic Hierarchy Process
Diterima 1 Februari 2014

\begin{abstract}
Generally, fishery resources are open access which means that anyone can participate without having these resources. This is shown by an increase in the utilization of fish resources that will lead to a crisis in which when the rate of exploitation goes beyond the ability of regeneration that makes the catches more economical (economic overfishing). Moreover, this will take place in conditions of uncontrolled fishing. The main factor causing this crisis is
\end{abstract}

the uncontrolled human intervention toward the existing fishery resources. The exploitation of these resources can lead to an imbalance between the input and the potential capture of fish resources so that it can lead to over-fishing, overcapacity, inefficiency arrest, resource rents decline, degradation of the resource stock and a decrease in production. The degradation impact of small pelagic fish resource, especially Layang fish in Ambon also is the reduction of producer welfare, especially the welfare of fishermen and coastal communities. This is due to, among others, the lack of control from the government as the authors, and the lack of understanding of resource actors (local fishermen) about the nature of fish resources which are open access. Thus, the calculation of the depreciation of small pelagic fish resources, especially lyang fish, and welfare aspects which are considered important to know as a point of reference as well as an early warning signal to determine whether the extraction of small pelagic fish resources, especially layang fish in Ambon has exceeded their capabilities.

\section{PENDAHULUAN}

Produksi sumberdaya ikan pelagis kecil dari tahun ke tahun mengalami peningkatan di Provinsi Maluku khususnya di Kota Ambon, seperti jenis-jenis ikan layang, kembung dan selar. Potensi dari sumberdaya ikan pelagis kecil tersebut sering dimanfaatkan oleh para nelayan, terutama yang berada dan bertempat tinggal di Kabupaten Maluku Tengah dan Kota Ambon. Dimana pada kedua wilayah ini menjadi pusat berlangsungnya kegiatan perikanan

\author{
Janer Sangaji \\ Universitas Pattimura Ambon \\ e-mail: janersangaji@gmail.com \\ Tridoyo Kusumastanto \\ Departemen Ekonomi Sumberdaya dan Lingkungan, Institut Pertanian Bogor \\ e-mail: tridoyo@indo.net.id \\ Sahat M.H. Simanjuntak \\ Departemen Ekonomi Sumberdaya dan Lingkungan, Insititut Pertanian Bogor \\ e-mail: sahat.simanjuntak@gmail.com
}


seperti perikanan tangkap yang telah berkembang pesat di Provinsi Maluku. Alat tangkap yang dominan yang digunakan untuk menangkap ikan pelagis kecil khususnya jenis ikan layang di Provinsi Maluku terdiri dari pukat cincin (purse seine), bagan (lift net), jaring insang (gill net), dan pukat pantai (beach seine). Dalam kurun waktu tahun 2004 sampai dengan 2008 jumlah unit alat tangkap serta produksi tangkapannya terus meningkat di Kabupaten Maluku Tengah sedangkan di Kota Ambon sendiri untuk jenis alat tangkap pukat cincin dan jaring insang cenderung meningkat namun produksinya relatif menurun.

Hal yang menarik terlihat pada data potensi produksi perikanan tangkap di Perairan Laut Banda yang dikeluarkan oleh Ditjen Perikanan Tangkap tahun 2002, mencatat bahwa pemanfaatan sumberdaya ikan pelagis kecil dan ikan demersal telah melebihi tangkapan yang diperbolehkan (Dinas Kelautan dan Perikanan Kota Ambon, 2005), terlihat dari data Statistik DKP tahun 2007 menunjukkan bahwa produksi ikan pelagis kecil pada WPP Laut Banda mencapai 146,47 ton per tahun sedangkan potensi estimasinya sebesar 132,00 ton per tahun (tingkat pemanfaatan lebih dari100 persen), atau telah melebihi potensi yang ada.

Perairan Kota Ambon menurut data statistika Departemen Perikanan dan Kelautan Nasional masuk dalam katagori yang kaya dengan banyak potensi laut (Sangadji, 2008). Berbeda dengan data tersebut, data sumberdaya ikan layang di perairan laut Kota Ambon menunjukkan bahwa jenis sumberdaya ini masih memiliki peluang pemanfaatan bahkan cenderung dapat ditingkatkan (DKP Provinsi Maluku, 2008). Perbedaan kedua data tersebut sangat krusial bagi perencanaan pengelolaan sumberdaya ikan yang berkelanjutan di Kota Ambon. Hal utama penyebab krisis tersebut adalah intervensi manusia yang tidak terkendali terhadap sumberdaya perikanan yang ada sehingga ekploitasi sumberdaya tersebut dapat menyebabkan ketidakseimbangan antara input penangkapan dan potensi sumberdaya ikan maka dapat mengarah pada kondisi tangkapan lebih (overfishing), kelebihan kapasitas, penurunan produksi, inefisiensi penangkapan, penurunan rente sumberdaya, serta terjadinya degradasi dan depresiasi sumberdaya.

Dampak degradasi dan depresiasi sumberdaya ikan layang di Perairan Kota Ambon juga mencakup berkurangnya kesejahteraan produsen, terutama kesejahteraan nelayan dan masyarakat pesisir. Hal tersebut disebabkan antara lain kurangnya kontrol dari pemerintah sebagai pemegang otoritas, dan kurangnya pemahaman pelaku sumberdaya (nelayan lokal) tentang sifat dari sumberdaya perikanan yang open acces. Dengan demikian perhitungan depresiasi sumberdaya ikan layang, dan aspek kesejahteraannya penting untuk diketahui sebagai referensi maupun early warning signal untuk mengetahui apakah ekstraksi sumberdaya ikan layang di Perairan Kota Ambon sudah melampaui kemampuan daya dukungnya. Penelitian-penelitian tentang sumberdaya ikan layang selama ini telah banyak dilakukan oleh beberapa peneliti. Khususnya di Perairan Kota Ambon penelitian yang berkaitan dengan pengelolaan berkelanjutan sumberdaya ikan layang belum pernah dilakukan. Adapun studi-studi terdahulu yang berkaitan dengan penelitian ini antara lain (Fitriyani Arifin, 2008 tentang optimasi perikanan layang), (Welhelmus Nabunome, 2007 tentang Model Analisis Bioekonomi dan Pengelolaan Sumberdaya Ikan Demersal), (Ambar Prihartini, 2006 tentang Analisis tampilan biologis ikan layang hasil tangkapan purse seine), Dari rujukan beberapa penelitian sebelumnya hasil yang membedakan dari penelitian ini lebih ditekankan terhadap penilaian depresiasi sumberdaya yang berdampak terhadap kesejahteraan hidup produsen dalam hal ini masyarkat nelayan local sehingga diharapkan melalui penelitian yang telah dilakukan ini terlihat bahwa akibat dari eksplotasi yang dilakukan makan sumberdaya menjadi terkuras dan overfishing secara biologi dan overfishing secara ekonomi terindikasi terjadi terhadap sumberdaya ikan layang. Untuk itu dengan melihat hasil yang telah di peroleh melalui penelitian ini akan dapat membuat suatu rumusan kebijakan agar sumberdaya ikan tetap lestari dan berkelanjutan. 
Penelitian ini bertujuan untuk mengetahui kondisi pemanfaatan sumberdaya ikan layang, nilai ekonomi, mengkaji laju depresiasi dan menentukan kebijakan pengelolaan sumberdaya ikan layang akibat dari jumlah aktifitas penangkapan di perairan Kota Ambon dengan menggunakan empat tahapan analisis antara lain analisis bioekonomi, analisis dinamis, analisis kesejahteraan produsen, dan penentuan kebijakan pengelolaan sumberdaya perikanan dilakukan dengan metode Analisis Hierarki Proses (AHP).

\section{METODOLOGI PENELITIAN}

\section{Lokasi dan Waktu}

Lokasi penelitian ditentukan secara sengaja (purposive), lokasi penelitian ini adalah di wilayah perairan Kota Ambon, Provinsi Maluku yang disajikan Gambar 1. Letak perairan Kota Ambon berada sebagian besar dalam wilayah pulau Ambon dan secara geografis terletak pada posisi: $3^{0}-4^{0}$ Lintang Selatan dan $128^{0}-129^{0}$ Bujur Timur, dimana secara keseluruhan Kota Ambon berbatasan dengan Kabupaten Maluku Tengah.

Penelitian ini dilaksanakan pada bulan September-November 2013 kegiatan penelitian merujuk pada tahapan pelaksanaan penelitian, mulai dari survei awal untuk pengumpulan data sekunder, pengumpulan data primer sampai pada analisis data dan penulisan.

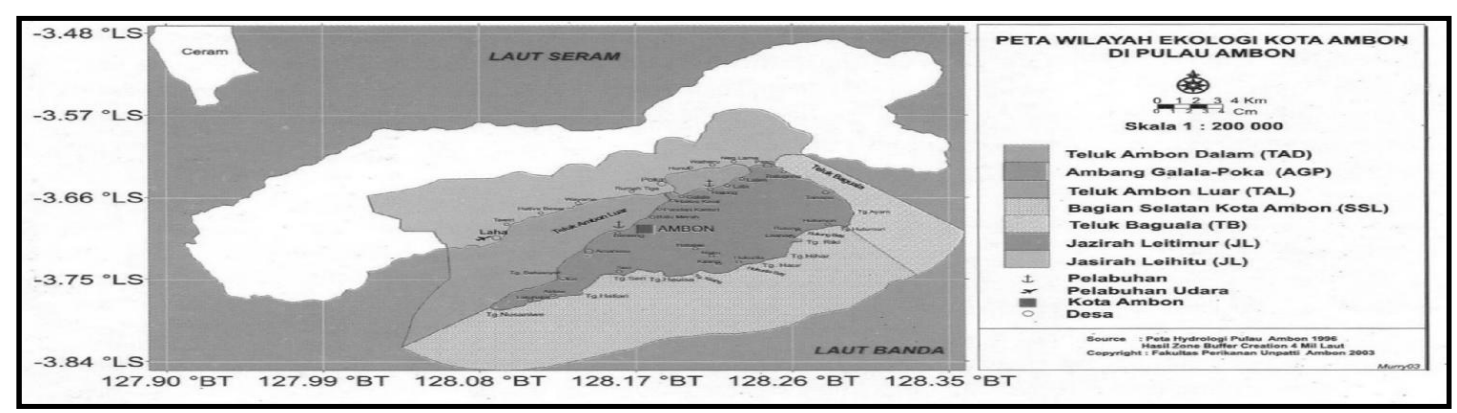

Gambar 1. Lokasi Penelitian,

Sumber: DKP Kota Ambon.

\section{Analisa Data}

Analisis data dalam penelitian ini terdiri dari analisis bioekonomi, analisis dinamis, analisis kesejahteraan produsen, dan penentuan kebijakan pengelolaan sumber daya perikanan dilakukan dengan metode Analisis Hierarki Proses (AHP) yang diuraikan sebagai berikut:

\section{Analisis Bioekonomi}

Suatu manfaat optimum dari kegiatan penangkapan ikan yang lestari pada perairan Kota Ambon diestimasi dengan menggunakan alat analisis bioekonomi. Pendekatan ini merujuk pada pendugaan parameter biologi dan pendugaan parameter ekonomi, antara lain:

\section{Pendugaan Parameter Biologi}

Pada pendugaan parameter biologi ini pertumbuhan populasi ikan diasumsikan mengikuti fungsi pertumbuhan logistik yang ditentukan oleh faktor biomas ikan $(x)$, pertumbuhan alamiah ikan $(r)$, kapasitas daya dukung lingkungan $(K)$. Kegiatan penangkapan ikan yang diupayakan oleh nelayan diasumsikan tergantung pada faktor input/upaya yang digunakan $(E)$, biomass ikan $(x)$, dan peluang tertangkapnya ikan $(q)$. Berdasarkan asumsi tersebut, maka estimasi fungsi produksi dihitung melalui persamaan berikut ini, (Fauzi, 2010): 
$\frac{\partial \mathrm{x}}{\partial \mathrm{t}}=\mathrm{x}=\mathrm{rx}\left(1-\frac{\mathrm{x}}{\mathrm{K}}\right)$
$\mathrm{h}=\mathrm{qxE}$

Dengan adanya penangkapan maka kedua persamaan tersebut di atas akan berubah menjadi persamaan berikut:

$$
\frac{\partial y}{\partial x}=r x=\left(1-\frac{x}{K}\right)-q x E
$$

Kemudian parameter biologi tersebut diduga dengan menggunakan pendekatan persamaan Clark, Yoshimoto, dan Pooley (1996) dalam Fauzi (2010) pada persamaan yang disederhanakan menjadi persamaan sebagai berikut:

$$
\begin{aligned}
& \ln \left(U_{t+1}\right)=\frac{2 r}{(2+r)} \ln (q K)+\frac{(2-r)}{2+r} \ln \left(U_{t}\right)-\frac{q}{2+r}\left(E_{t}+E_{t+1}\right) \\
& \ln \left(U_{t+1}\right)=\beta 1+\beta 2 \ln \left(U_{t}\right)+\beta 3\left(E_{t}+E_{t+1}\right)
\end{aligned}
$$

maka hasil pendugaan akan digunakan untuk menghitung parameter biologi $r, q$, dan $K$, dengan menggunakan persamaan sebagai berikut:

$$
\begin{aligned}
& \mathrm{r}=\frac{2(1-\beta 2)}{(1+\beta 2)} \\
& \mathrm{q}=-\beta 3(2-\mathrm{r}) \\
& \mathrm{K}=\frac{\mathrm{e}^{\frac{\beta 1(2+\mathrm{r})}{(2 \mathrm{r})}}}{\mathrm{q}}
\end{aligned}
$$

Selanjutnya nilai yang diperoleh digunakan untuk mengestimasi stok $(x)$, dan jumlah tangkapan $(h)$ yang dihitung dengan persamaan sebagai berikut:

\begin{tabular}{|c|c|c|c|}
\hline \multirow{2}{*}{ Variabel } & \multicolumn{3}{|c|}{ Rezim Pengelolaan } \\
\hline & MEY & MSY & Open Acces \\
\hline Biomassa & $\mathrm{K}(1, \mathrm{C})$ & $K$ & $C$ \\
\hline$(\mathrm{x})$ & $\overline{2}(1+\overline{\mathrm{pqK}})$ & $\overline{2}$ & $\overline{p q}$ \\
\hline Hasil Tangkapan (h) & $\underline{r K}\left(1+\frac{c}{c}\right)\left(1-\frac{c}{c}\right)$ & $r K$ & $\left(\frac{r c}{-}\right)\left(1-\frac{c}{-}\right)$ \\
\hline & $\overline{4}(1+\overline{p q K})(1-\overline{p q K})$ & $\overline{4}$ & $(\overline{p q})(1-\overline{p q K})$ \\
\hline Tingkat Upaya & $\frac{r}{n}\left(1-\frac{c}{}\right)$ & $r$ & $\frac{r}{-}\left(1-\frac{c}{}\right)$ \\
\hline (E) & $\overline{2 q}(1-\overline{p q K})$ & $\overline{2 q}$ & $\bar{q}(1-\overline{p q K})$ \\
\hline $\begin{array}{l}\text { Rente Sumberdaya } \\
\qquad(\pi)\end{array}$ & $p q K E\left(1-\frac{q E}{r}\right)-c E$ & $-c\left(\frac{r}{2 q}\right)$ & $p-\left(\frac{c}{p x}\right) F(x)$ \\
\hline
\end{tabular}

$$
\begin{aligned}
& \mathrm{x}=\mathrm{K}\left[1-\frac{\mathrm{qE}}{\mathrm{r}}\right] \\
& h=q K E\left[1-\frac{q E}{r}\right]
\end{aligned}
$$

Fauzi (2010), menjelaskan pada kondisi MSY biomas $(x)$ kemudian tangkapan $(h)$ dihitung dengan upaya tangkapan $\left(\mathrm{E}_{\mathrm{msy}}\right)$ dengan persamaan sebagai berikut:

$$
\begin{aligned}
& \mathrm{E}_{\mathrm{msy}}=\frac{\mathrm{r}}{2 \mathrm{q}} \\
& \mathrm{h}_{\mathrm{msy}}=\frac{\mathrm{rK}}{4} \\
& \mathrm{X}_{\text {msy }}=\frac{\left(\frac{\mathrm{rk}}{4}\right)}{\mathrm{q}\left(\frac{\mathrm{r}}{2 \mathrm{q}}\right)}=\frac{\mathrm{K}}{2}
\end{aligned}
$$

Tabel 1. Formula Solusi Bioekonomi Statis

Sumber: Fauzi (2004)

\section{Pendugaan Parameter Ekonomi}

Pendugaan parameter ekonomi dilakukan melalui perhitungan dan estimasi terhadap biaya produksi (operasional penangkapan), dan harga ikan. Variabel biaya operasional diestimasi dari rata-rata biaya yang dikeluarkan oleh nelayan per trip dalam melakukan aktivitas penangkapan. Perhitungan biaya per trip dilakukan dengan menggunakan persamaan 45. Parameter harga ikan diestimasi dengan harga riil ikan yang diperoleh dari konversi harga nominal tahun 1995-2010 dengan penyesuaian dengan IHK. Jika telah mengetahui nilai harga, biaya dan tangkapan, maka dapat dilakukan penghitungan besaran penerimaan total lestari penangkapan ikan dengan persamaan-persamaan sebagai berikut:

$$
\begin{aligned}
& \mathrm{TC}: \mathrm{cE} \\
& \mathrm{P}_{\text {riil }}:\left(\frac{\mathrm{P}_{\text {nominal }}}{\mathrm{IHK}}\right) \times 100
\end{aligned}
$$




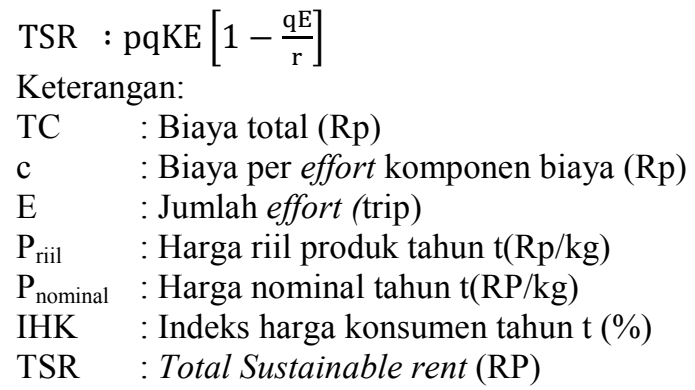

Dari ketiga persamaan di atas maka nilai rente ekonomi dari penangkapan ikan dapat dihitung dengan persamaan berikut ini:

Rente Ekonomi $(\pi)=\operatorname{pqKE}\left[1-\frac{\mathrm{qE}}{\mathrm{r}}\right]-\mathrm{cE}$

Hasil estimasi parameter biologi dan parameter ekonomi di Perairan Kota Ambon selanjutnya dikombinasikan, sehingga akan diperoleh selisih suatu kurva bioekonomi pada Perairan Kota Ambon. Dengan demikian selisih kurva tersebut dapat digunakan untuk menghitung perbedaan kondisi pada empat kecamatan yang diteliti pada Perairan Kota Ambon.

\section{Standarisasi CPUE Alat Penangkapan Ikan}

Analisis CPUE ditujukan untuk mengestimasi upaya alat tangkap di setiap titik pengamatan. Unit effort sejumlah armada penangkapan ikan dengan alat tangkap dan waktu tertentu dikonversi ke dalam satuan "boat-days" (trip). Pertimbangan trip yang digunakan adalah: (1) respon stok terhadap alat tangkap standard akan menentukan status sumber daya yang selanjutnya berdampak pada status perikanan alat tangkap lain; (2) total hasil tangkapan ikan per unit effort alat tangkap standard lebih dominan dibandingkan dengan alat tangkap lain; dan (3) daerah penangkapan alat tangkap standard berhubungan dengan daerah penangkapan alat tangkap lainnya. Pertimbangan beragamnya alat tangkap yang digunakan di lokasi penelitian, maka dilakukan standardisasi upaya tangkap antar alat. Standardisasi ini ditujukan untuk melakukan pengukuran upaya tangkap masing-masing alat dengan satuan pengukuran yang setara. Teknik standardisasi yang digunakan mengikuti persamaan yang dikembangkan oleh King (1995) diacu dalam Anna (2003):

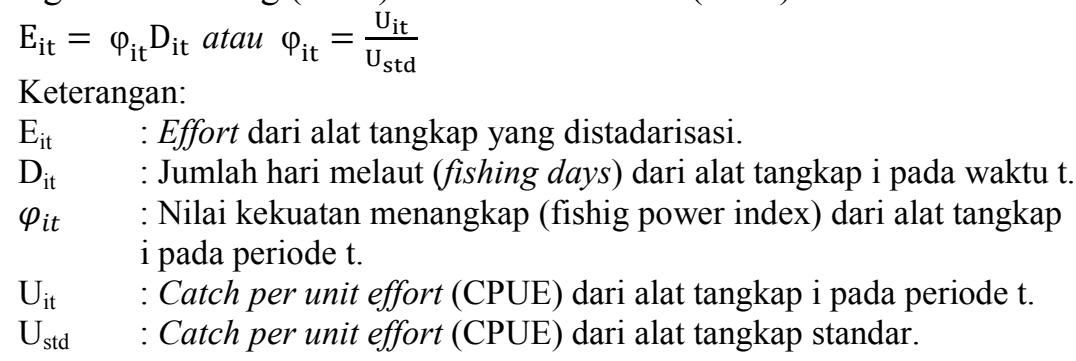

\section{Analisis Degradasi dan Depresiasi}

Kemudian untuk menghitung degradasi dan depresiasi sumberdaya perikanan dengan metode present value, maka seluruh rente yang akan datang, yang diharapkan dihasilkan dari sumberdaya perikanan, dihitung dalam nilai dimasa sekarang (present value) dengan asumsi bahwa kurva permintaan bersifat elastis maka rente sumberdaya perikanan dihitung berdasarkan persamaan:

\section{Keterangan:}

$$
\pi_{t}=\left(a-b h_{t}\right) h_{t}-c_{t} E_{t}=U\left(h_{t}\right)-c E_{t}
$$

$\pi_{\mathrm{t}} \quad$ : Rente sumberdaya perikanan

$a \quad$ : Intersep kurva permintaan.

$b \quad$ : Slope (kemiringan).

$h_{t} \quad$ : Tangkapan lestari.

$c_{t} \quad$ : Biaya per unit upaya.

$U\left(h_{t}\right)$ : Utilitas (manfaat) yang dihasilkan dari sumberdaya perikanan. 
E : Tingkat upaya.

t $\quad$ : Periode waktu.

Tangkapan lestari disumsikan mengkikuti fungsi Gompertz, yaitu:

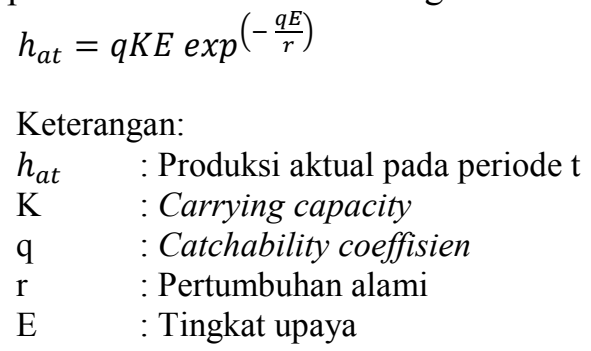

Parameter K, q, dan $\mathrm{r}$ adalah parameter biologi yang kemudian diestimasi melalui prosedur Clark Yoshimoto dan Pooley (CYP). Sehingga present value dari rente perikanan pada periode tidak terbatas $(\mathrm{t}=0$ sampai tak terhingga) adalah sebagai berikut:

$$
\mathrm{V}_{\mathrm{t}}=\frac{\pi_{\mathrm{t}}}{\delta}
$$

maka $\delta=$ nilai discount rate. Perubahan present value dari sumberdaya antara periode $(\mathrm{t}-1)$ dan $(\mathrm{t}), \mathrm{V}_{\mathrm{t}}-\mathrm{V}_{\mathrm{t}-1}$, menyebabkan nilai bersih perubahan dalam stok sumberdaya terdepresiasi sebagai berikut:

$$
\begin{aligned}
& \left(\mathrm{V}_{\mathrm{t}}-\mathrm{V}_{\mathrm{t}-1}\right)=\frac{\left(\pi_{\mathrm{t}-} \pi_{\mathrm{t}-1}\right)}{\delta} \\
& \text { Keterangan: } \\
& \mathrm{V}_{\mathrm{t}}=\mathrm{V}\left(\mathrm{h}_{\mathrm{t}}, \mathrm{p}_{\mathrm{t}}\left(\mathrm{h}_{\mathrm{t}}\right), \mathrm{E}_{\mathrm{t}}, \mathrm{c}_{\mathrm{t}}, \delta\right), \text { dan } \\
& \mathrm{V}_{\mathrm{t}-1}=\mathrm{V}\left(\mathrm{h}_{\mathrm{t}-1}, \mathrm{p}_{\mathrm{t}-1}\left(\mathrm{~h}_{\mathrm{t}-1}\right), \mathrm{E}_{\mathrm{t}-1}, \mathrm{c}_{\mathrm{t}-1}, \delta\right), \text { dengan } \\
& \mathrm{P}=\text { harga produksi ikan per satuan berat. } \\
& \text { atau }
\end{aligned}
$$

Dapat ditulis juga dengan persamaan model analisis sumberdaya ikan menurut Fauzi dan Anna (2005) berikut ini:

- Degradasi sumberdaya ikan:

$$
\varnothing=\frac{1}{1+e^{\frac{h_{a t}}{h_{s t}}}}
$$

Keterangan:

$\varnothing \quad$ : Laju degradasi

$h_{a t} \quad$ : Produksi aktual pada periode $\mathrm{t}$

$h_{s t} \quad$ : Produksi lestari pada periode $\mathrm{t}$

- Depresiasi sumberdaya ikan:

Keterangan:

$$
\begin{aligned}
\pi_{t}-\pi_{t-1} & =\left[p h_{s t}-c E_{t}\right]-\left[p h_{s t-1}-c E_{t-1}\right] \\
& =(p-c)\left[\left(h_{s t}-h_{s t-1}\right)+\left(E_{t}-E_{t-1}\right)\right]
\end{aligned}
$$

$\pi_{\mathrm{t}} \quad$ : Rente sumberdaya perikanan

$h_{s t} \quad$ : Produksi lestari.

$p \quad$ : Harga output

c : Tingkat upaya.

E : Input

$\mathrm{t} \quad$ : Periode waktu.

\section{Analisis model dinamis}

Dalam modeling terdapat empat tujuan; Pertama, memungkinkan merubah bagianbagian dan percobaan-percobaan yang berpengaruh terhadap perubahan sistem; Kedua, memberikan rangkaian pengetahuan tentang sistem dinamik; Ketiga, memberi petunjuk lebih lanjut mengenai pertanyaan-pertanyaan tentang sistem, apa yang mendasari perilaku sistem, dan bagaimana dasar-dasar yang dapat dipakai dan yang diketahui dalam proses sistem yang lain; dan Keempat, memahami perlengkapan dari sistem (Ruth dan Hannon, 1994). Pendekatan model dinamik diperlukan untuk memahami pengelolaan aspek ekonomi 
sumberdaya secara menyeluruh (Fauzi, 2004). Model dinamis mampu menelusuri jalur waktu antar peubah-peubah model dan dapat memberikan kekuatan yang lebih tinggi pada analisis dunia nyata. Tahapan dalam melakukan analisis dinamik adalah:

1. Analisis kebutuhan

2. Formulasi permasalahan

3. Identifikasi dan Pemodelan Sistem.

Simulasi model dalam pengelolaan sumberdaya ikan layang di Perairan Kota Ambon menggunakan perangkat lunak Stellarium dan Powersim. Program Stellarium dan Powersim dapat mengkaji berbagai skenario kebijakan pemanfaatan sumberdaya perikanan tangkap yang berpengaruh pada pendapatan dan kesejahteraan nelayan. Powersim merupakan model untuk mengabstraksi masalah yang kompleks menjadi sederhana. Selain itu Powersim adalah model yang menggambarkan hubungan antara satu variabel dengan variabel lainnya dalam satu sistem yang saling terkait. Simulasi model ini terdiri dari beberapa sub model yaitu : (1) Sub model sumber daya perikanan (SDI) yang menggambarkan biomassa, daya dukung lingkungan (K), dan pertumbuhan intrinsik (r). (2) Sub model upaya tangkap (effort) yang menggambarkan jumlah effort (unit) dan kemampuan tangkap $(q)$. Setelah dilakukan simulasi model, langkah selanjutnya adalah interpretasi dari model tersebut untuk mengetahui kecenderungan di masa mendatang. Selain itu agar dapat memahami masalah internal secara lebih rinci. Pemahaman ini berguna untuk memberi solusi yang terbaik dalam pengambilan keputusan guna menghasilkan kebijakan dalam pengelolaan sumberdaya perikanan.

7. Analisis Kesejahteraan Produsen

Analisis Kesejahteraan Produsen serta perubahan surplus produsen dihitung berdasarkan persamaan berikut:

$$
\begin{aligned}
& \mathrm{PS}=\mathrm{p}_{0} \mathrm{~h}_{0}-\int_{0}^{\mathrm{h}_{0}} \frac{2 \mathrm{c}}{\alpha+\sqrt{-4 \beta \mathrm{h}+\alpha^{2}}} \\
& \text { Keterangan: } \\
& \mathrm{PS} \quad \text { : Producer surplus. } \\
& \mathrm{p}_{0} \quad \text { : Harga pada periode awal. } \\
& \mathrm{h}_{0} \quad \text { : Tangkapan lestari. } \\
& \mathrm{c} \quad \text { : Biaya. }
\end{aligned}
$$

$\alpha$ dan $\beta$ : Koefisien-koefisien penangkapan lestari (Sustainable yield).

Bentuk persamaan diatas ada yang bersifat fungsional dan statistik. Persamaanpersamaan tersebut kemudian dianalisis dengan bantuan software komputer Exel dan MAPLE. Analisis kesejahteraan produsen dan depresiasi suatu aktivitas perikanan terhadap sumberdaya ikan layang di Perairan Kota Ambon diukur dengan surplus produsen sebagai proxy, analisis surplus produsen dilakukan didasarkan pada sifat dari sumberdaya perikanan yang memiliki kurva suplai melengkung ke belakang (backward bending supply/variabel price model). Dengan menggunakan parameter biofisik dan ekonomi yang telah dihitung, maka diperoleh surplus produsen kondisi baseline pada setiap tahunnya.

\section{Analisis Kebijakan}

AHP membantu dalam menentukan prioritas dari beberapa kriteria dengan melakukan analisa perbandingan berpasangan dari masing-masing kriteria. Dalam sistem pengelolaan kinerja yang dimaksud dengan kriteria tersebut adalah KPI. Ada tiga prinsip dalam memecahkan persoalan dengan AHP, yaitu prinsip menyusun hierarki (Decomposition), prinsip menentukan prioritas (Comparative Judgement), dan prinsip konsistensi logis (Logical Consistency). Secara umum, langkah-langkah dasar dari AHP dapat diringkas dalam penjelasan berikut ini:

1. Mendefinisikan masalah dan menetapkan tujuan.

2. Menyusun masalah dalam struktur hirarki.

3. Menyusun prioritas untuk tiap elemen masalah pada tingkat hirarki. 
Analisis Hierarki Proses (AHP) digunakan sebagai salah satu model dalam penentuan arah kebijakan atas suatu masalah yang terhadap pengelolaan sumberdaya perikanan layang di Perairan Kota Ambon penentuan kebijakan tersebut didasarkan pada kondisi yang ada pada perikanan layang di Perairan Kota Ambon oleh karena dalam merumuskan alternatif kebijakan dibutuhkan peran pemerintah dalam hal ini penjabat dan pakar dibidang perikanan dengan menggunakan Analisis Hierarki Proses (AHP) agar dapat memperoleh beberapa orang yang mewakili pemerintah agar dapat memperoleh informasi tentang arah kebijakan yang perlu dirumuskan dalam pengelolaan sumberdaya perikanan layang di Perairan Kota Ambon.

Saaty (1983), menjelaskan berbagai persoalan, skala 1 sampai 9 adalah skala terbaik dalam mengekspresikan pendapat. Menurut Marimin (2004), untuk memeriksa apakah perbandingan berpasangan telah dilakukan dengan konsekuen digunakan parameter Consistency Ratio (CR).

Tabel 2. Matriks Bentuk Perbandingan Berpasangan

\begin{tabular}{|c|c|c|c|c|}
\hline Kriteria & Alternatif 1 & Alternatif 2 & Alternatif 3 & Alternatif $f_{n}$ \\
\hline Alternatif1 & 1 & & & \\
\hline Alternatif2 & & 1 & & \\
\hline Alternatif3 & & & 1 & \\
\hline Alternatif $_{n}$ & & & & 1 \\
\hline
\end{tabular}

Sumber: Marimin 2008

Analisis Hierarki Proses (AHP) memiliki beberapa prosedur antara lain menggabungkan pendapat responden para ahli, namun kadang ditemukan penelitian beberapa ahli terindikasi multidisipliner sehingga perlu dilakukan cek ulang terhadap pendapat para ahli tersebut. Apabila telah mendapatkan pendapat yang konsisten maka digabungkan dengan menggunakan, persamaan berikut:

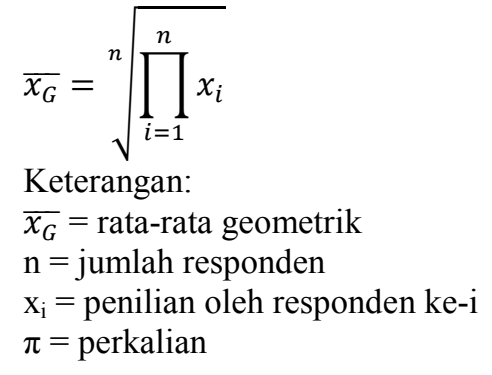

\section{HASIL DAN PEMBAHASAN}

\section{Hubungan CPUE dan Effort SDI Layang}

CPUE dan effort memiliki hubungan sangat kuat di mana dalam hal ini hubungan terbalik, yaitu apabila upaya penangkapan ditingkatkan maka CPUE akan menurun, begitu juga sebaliknya apabila upaya penangkapan diturunkan maka CPUE akan naik. Hubungan CPUE dengan effort pada periode tahun 1995 hingga 2009 yang ditunjukkan pada Gambar 2. Gambar 2 menunjukkan hubungan antara effort dan CPUE sumberdaya ikan layang ditunjukkan dengan hasil OLS dengan MS. Excel 2010 diperoleh nilai $\alpha=-1,44944, \beta=$ $0,64788, \quad \gamma=-2,85172$ persamaan $\mathrm{yt}=-1,44944+0,64788 \mathrm{x}_{1 \mathrm{t}}-2,85172 \mathrm{x}_{2 \mathrm{t}}$, sehingga diperoleh intersep sebesar $-1,44944$, nilai variabel $\mathrm{x}_{1}$ sebesar 0,64788 dan variabel $\mathrm{x}_{2}$ sebesar $-2,8517$ terlihat tren peningkatan mulai terjadi pada tahun 1995 dengan effort sebesar 125,17 trip dan CPUE sebesar 0,0072 ton per trip hingga periode tahun 2009 dengan effort sebesar 310,08 dan CPUE sebesar 0,00026 ton per trip yang diikuti dengan menurunnya produksi periode 1995 hingga 2009 dengan rata-rata produksi sebesar 317,58 ton berarti bahwa setiap peningkatan satu satuan effort akan menurunkan nilai produktivitas hasil tangkapan dan terindikasi terjadinya overfishing. 


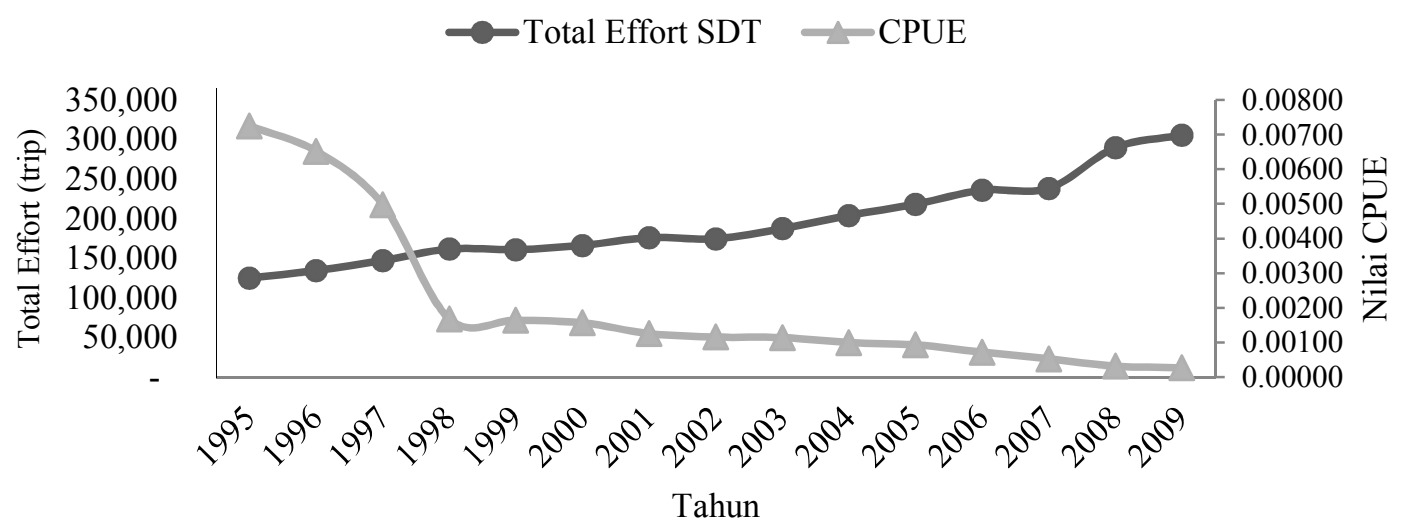

Gambar 2. Hubungan CPUE dan Effort SDI Layang, Sumber: Data Primer (diolah) 2014

Hal ini menjelaskan bahwa penurunan produksi yang cukup tajam ini karena jumlah stok dari sumberdaya ikan sudah mengalami penurunan, maka kondisi pemanfaatan sumberdaya ikan layang di Perairan Kota Ambon telah terindikasi mengalami tangkap lebih (overfishing).

\section{Analisis Produksi Lestari}

Banyak model yang biasa digunakan dalam mengestimasi produksi lestari sumberdaya perikanan, namun dalam penelitin ini menggunakan model CYP. Penggunaan model tersebut dimulai dengan menentukan tingkat upaya penangkapan per unit alat tangkap purse seine dan bagan yang kemudian diregresikan, maka estimasi parameter biologi dapat dilakukan dengan mengestimasi produksi lestari.

\section{Estimasi Parameter Biologi}

Dalam penelitian ini parameter biologi dianalisis dengan menggunakan model estimasi CYP, yang terdiri dari tingkat konstanta pertumbuhan alami $(r)$, koefisien tangkap $(q)$ dan daya dukung biomass $(K)$ yang dapat dieksploitasi oleh unit alat tangkap purse seine dan bagan di Perairan Kota Ambon. Estimasi dilakukan terhadap sumberdaya ikan layang yang didasarkan pada data tahunan hasil tangkapan per satuan upaya dan upaya tangkapan (effort) dimana terdapat model produksi surplus telah diterapkan untuk menentukan hubungan antara hasil tangkapan per satuan upaya dan upaya tangkapan yang dioperasikan oleh unit alat tangkap purse seine dan bagan di Perairan Kota Ambon. Sesuai hasil analisis statistik, hubungan antara peubah dengan menggunakan model CYP memperlihatkan nilai terbaik dari ketiga model yang lain. Model CYP memperlihatkan nilai koefisien determinannya sebesar 91,64 persen. Hasil analisis data tersebut disajikan pada Tabel 2 berikut.

Tabel 3. Hasil Regresi Model CYP

\begin{tabular}{|c|c|c|}
\hline Model & Uji Statistik & Nilai Statistik \\
\hline \multirow{2}{*}{ CYP } & Koefisien determinan & 0,9164 \\
\hline & F hitung regresi & 72,31 \\
\hline
\end{tabular}

Sumber: Data diolah, 2014.

Dari hasil regresi, kemudian digunakan pendugaan parameter biologi perikanan di Kota Ambon. Dalam hal ini, konstanta pertumbuhan alami $(r)$, koefisien kemampuan daya tangkap $(q)$ dan daya dukung biomass $(K)$ yang dapat dihitung dengan model CYP (Clark, Yoshimoto, dan Pooley,1996). Hasil estimasi parameter biologi tersebut disajikan di Tabel 4. 
Tabel 4. Hasil Estimasi Fungsi Logistik Parameter Biologi dengan Model CYP

\begin{tabular}{cc}
\hline Parameter & CYP \\
\hline$r$ & 0,42734 \\
$q$ & 0,0000069 \\
$K$ & $2.355,08$ \\
\hline
\end{tabular}

Sumber: Data diolah, 2014.

Hasil estimasi fungsi logistik pada model CYP menunjukkan bahwa koefisien nilai laju pertumbuhan alami $(r)$ sebesar 0,42734 estimasi kemampuan daya tangkap $(q)$ sebesar 0,0000069 berarti parameter koefisien tangkapan pada model CYP mengindikasikan setiap peningkatan satu satuan upaya penangkapan akan menghasilkan produksi sebesar 0,0000069 ton per trip sementara daya dukung perairan $(K)$ merupakan ekosistem pendukung produksi sumberdaya ikan layang yakni sebesar $2.355,08$ ton per tahun. Hasil estimasi parameter biologi $(r, q$, dan $K)$ pada model CYP berguna dalam menentukan tingkat produksi lestari pada tingkat Maximum Sustainable Yield (MSY).

\section{Analisis Bioekonomi}

Pada Tabel 5 tingkat produksi aktual $(h)$ sumberdaya ikan layang di Perairan Kota Ambon selama periode tahun 1995 hingga tahun 2009 sebesar 317,58 ton per tahun, produksi $(h)$ aktual ini lebih besar dibandingkan dengan produksi $(h)$ optimal sebesar 241,11 ton per tahun dengan kondisi pengelolaan OA sebesar 163,57 ton per tahun.

Tabel 5. Hasil bioekonomi berbagai rezim pengelolaan sumberdaya ikan layang dengan model CYP

\begin{tabular}{|c|c|c|c|c|}
\hline Model & $\begin{array}{c}\text { Biomassa }(\mathrm{x}) \\
\text { (ton) }\end{array}$ & $\begin{array}{l}\text { Produksi (h) } \\
\text { (ton) }\end{array}$ & $\begin{array}{c}\text { Effort (E) } \\
\text { (trip) }\end{array}$ & $\begin{array}{c}\pi \\
\text { (Rp juta) }\end{array}$ \\
\hline Solo Owner/ MEY & $1.418,03$ & 241,11 & $24.564,00$ & $10.789,63$ \\
\hline Open Acces & 480,99 & 163,57 & $49.128,00$ & 0,00 \\
\hline MSY & $1.177,53$ & 251,60 & $30.868,00$ & $10.078,92$ \\
\hline Aktual & - & 317,58 & $192.318,00$ & $(21.855,01)$ \\
\hline
\end{tabular}

\section{Sumber : Data Primer}

Kemudian effort aktual sumberdaya ikan layang selama periode tahun 1995 hingga 2009 memiliki nilai effort sebesar 192,31 trip per tahun lebih besar dibandingkan dengan nilai effort pada tingkat optimal sebesar 24,56 trip per tahun, kemudian kondisi pengelolaan MSY sebesar 30,86 trip per tahun dan kondisi OA sebesar 49,12 trip per tahun dengan tingkat rente ekonomi aktual sebesar Rp. $(21.855,01)$ per tahun terlihat bahwa terdapat perbedaan jumlah selisih yang besar berarti bahwa terjadi peningkatan effort dan berkurangnnya hasil tangkapan sumberdaya ikan layang, sehingga total biaya yang dikeluarkan tidak akan sebanding dengan hasil tangkapan yang diperoleh.

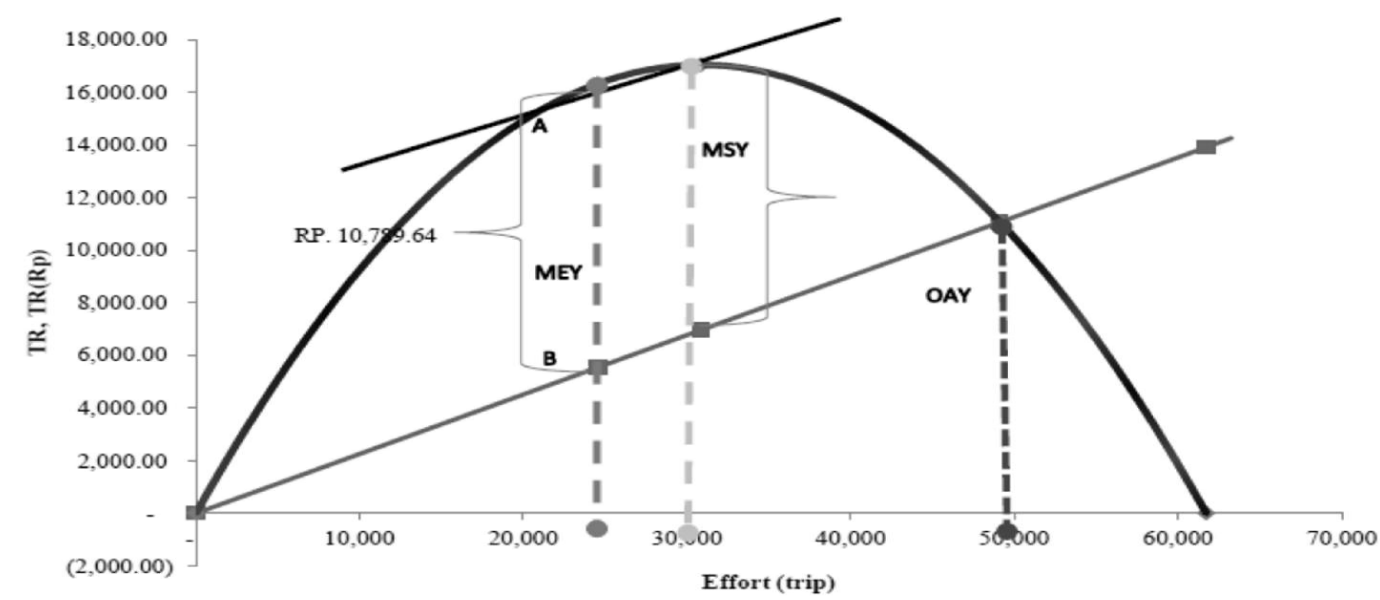

Gambar 3. Kurva Bioekonomi Berbagai Rezim Pengelolaan 
Upaya penangkapan aktual terhadap sumberdaya ikan layang telah melebihi upaya optimum baik pada kondisi $M E Y$ maupun $M S Y$. Hal tersebut mengindikasikan bahwa sumberdaya ikan layang di Kota Ambon telah mengalami overfishing baik secara biologi maupun secara ekonomi. Kecenderungan ini menyebabkan tingkat upaya tangkap ikan meningkat hingga tercapai keseimbangan/rent aktual bernilai negatif yakni tidak lagi diperoleh keuntungan dari pemanfaatan sumberdaya ikan tersebut (Gordon 1954 dalam Zulbainarni 2012) maka daerah tersebut telah mengalami tangkap lebih (overfishing).

Dengan hasil analisis rata-rata laju degradasi dan depresiasi 0,28 dan 0,59 menunjukkan nilai koefisien depresiasi sumberdaya ikan layang ditunjukkan pada Gambar 2 periode tahun 1997, 1998, 1999, 2000, 2002, 2003, 2004, 2005, 2006 dan 2009 terindikasi mengalami depresiasi karena nilai koefisien depresiasi telah melebihi batas nilai toleransi 0,5 persen tetapi belum terjadi degradasi. Seperti yang terlihat hampir keseluruhan laju depresiasi telah terjadi pada periode 1995 hingga 2009 sedangkan laju degradasi masih berada dibawah batas nilai toleransi 0,5 persen. Terlihat pada Gambar 2 pada kondisi laju depresisasi terjadi

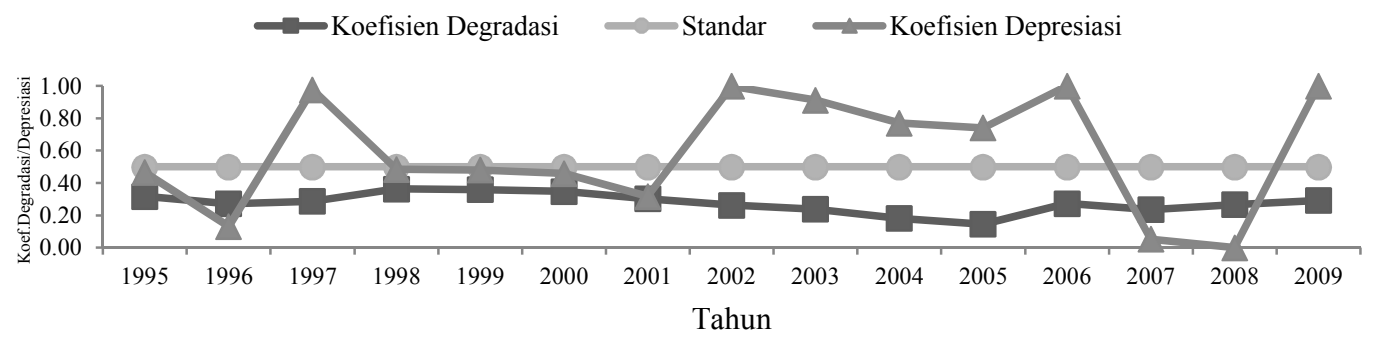

Gambar 4. Laju Koefisien degradasi dan depresiasi sumberdaya ikan layang.

loncatan yang tajam pada beberapa tahun yang terindikasi megalami depresiasi. Secara teori dapat dijelaskan bahwa dalam hal kajian depresiasi sumberdaya ikan layang ini terdapat hubungan terbalik, ketika terjadi peningkatan effort akan menyebabkan menurunnya nilai sumberdaya ikan layang atau sumberdaya tersebut semakin terdepresiasi, dan sebaliknya penurunan effort akan menyebabkan peningkatan terhadap nilai sumberdaya atau terapresiasinya nilai dari sumberdaya.

\section{Nilai Depresiasi Sumberdaya Ikan Layang di Perairan Kota Ambon}

Pendekatan yang dipakai dalam menilai depresiasi dengan menggunakan present value of rent (PVR) yang menggambarkan manfaat yang akan datang yang dinilai pada saat ini yakni manfaat akan datang dari kapital (stock) oleh masyarakat yang diperoleh sekarang dengan tingkat discount rate tertentu. Perubahan nilai manfaat sekarang tersebut yang

Tabel 6. Nilai Depresiasi Sumberdaya Ikan Layang di Perairan Kota Ambon

\begin{tabular}{cccccrr}
\hline \multirow{2}{*}{ Tahun } & $\begin{array}{c}\text { Effort } \\
\text { (trip) }\end{array}$ & $\begin{array}{c}\text { Prod. Lestari } \\
\text { (ton) }\end{array}$ & $\begin{array}{c}\text { PV Rent 05.65\% } \\
\text { (Rp) }\end{array}$ & $\begin{array}{c}\text { Depresiasi 05,65\% } \\
\text { (Rp) }\end{array}$ & $\begin{array}{c}\text { PV Rent 18\% } \\
\text { (Rp) }\end{array}$ & $\begin{array}{c}\text { Depresiasi } 18 \% \\
(\mathrm{Rp})\end{array}$ \\
\hline 1995 & 125,17 & 699,03 & $20.745,04$ & $20.745,04$ & $6.511,63$ & $6.511,63$ \\
1996 & 134,72 & 865,50 & $18.064,72$ & $-2.680,32$ & $5.670,31$ & $-841,32$ \\
1997 & 147,32 & 665,97 & $-201.859,77$ & $-219.924,49$ & $-63.361,53$ & $-69.031,85$ \\
1998 & 150,65 & 141,50 & $9.505,95$ & $211.365,72$ & $2.983,81$ & $66.345,35$ \\
1999 & 151,32 & 143,18 & $12.968,52$ & $3.462,57$ & $4.070,67$ & $1.086,86$ \\
2000 & 155,20 & 153,23 & $25.134,65$ & $12.166,13$ & $7.889,48$ & $3.818,81$ \\
2001 & 161,13 & 169,18 & $45.640,36$ & $20.505,70$ & $14.326,00$ & $6.436,51$ \\
2002 & 174,76 & 208,65 & $105.312,70$ & $59.672,33$ & $33.056,48$ & $18.730,48$ \\
2003 & 187,55 & 249,26 & $170.603,69$ & $65.290,99$ & $53.550,60$ & $20.494,11$ \\
2004 & 204,20 & 307,28 & 100.515 .38 & $-70.088,31$ & $31.550,66$ & $-21.999,94$ \\
2005 & 218,31 & 361,07 & $145.091,18$ & $44.575,80$ & $45.542,50$ & $13.991,84$ \\
2006 & 235,99 & 167,07 & $-42.937,87$ & $-188.02,05$ & $-13.477,72$ & $-59.020,23$ \\
2007 & 238,41 & 148,30 & $-66.784,79$ & $-23.846,92$ & $-20.963,00$ & $-7.485,28$ \\
2008 & 289,88 & 94,40 & $-156.861,45$ & $-90.076,65$ & $-49.237,06$ & $-28.274,06$ \\
2009 & 310,08 & 73,94 & $-169.720,10$ & $-12.858,65$ & $-53.273,25$ & $-4.036,18$ \\
\hline Rataan & 192,31 & 296,51 & $102.788,15$ & $-11.314,67$ & 322,64 & $-3.551,55$ \\
\hline Sum & & & & &
\end{tabular}

Sumber: Data diolah, 2014. 
berpengaruh terhadap tingkat kesejahteraan nelyan sekarang dan akan datang. Perubahan manfaat sekarang inilah yang diukur sebagai nilai depresiasi yang dirupiahkan. Tabel 6 menunjukkan perubahan nilai depresiasi sumberdaya ikan layang tahun 1995 hingga 2009 dengan tingkat market discount rate 18 persen terlihat mengalami depresiasi selama kurun waktu tahun 1997, 2006, 2007, 2008 dan 2009 sedangkan tahun 1995, 1996, 1998 sampai 2005 menunjukkan kondisi perbaikan (recovery) secara keseluruhan dari hasil estimasi dengan rata-rata (PVR) sebesar Rp.322,64 juta. Perhitungan rente sumberdaya ikan layang dengan menggunakan discount rate yang lebih konservatif 05,65 persen menghasilkan nilai present value of rent yang lebih tinggi dari perhitungan rente dengan market discout rate dengan rata-rata (PVR) sebesar Rp.102.788,15 juta. Hal ini terlihat pada Gambar 5 dan 6 menunjukkan hubungan rente ekonomi dan lestari terhadap depresiasi, terlihat bahwa semakin kecil tingkat PVR lestari maka semakin tinggi nilai depresiasi. Nilai PVR lestari yang tinggi menggambarkan tingkat produksi lestari yang tinggi sekaligus berdampak pada tingkat eksploitasi ikan oleh nelayan menjadi rendah.

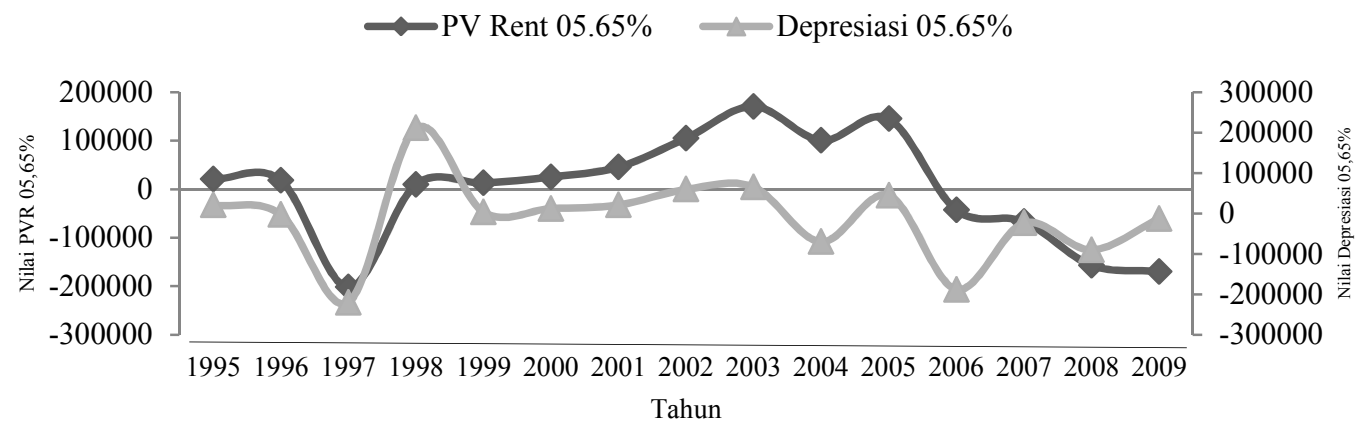

Gambar 5. PVR Lestari dan Depresiasi Sumberdaya ikan Layang (discount rate 5,65\%)

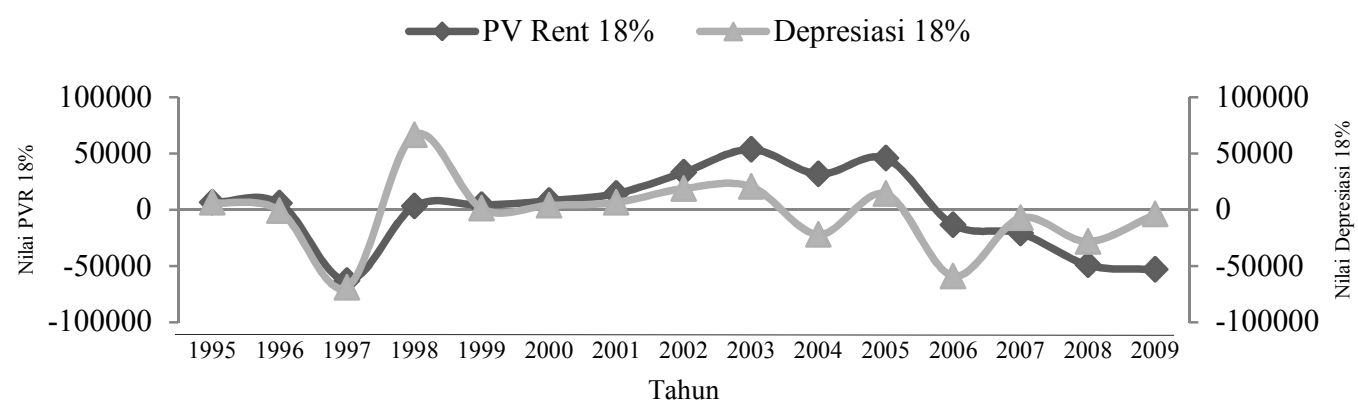

Gambar 6. PVR Lestari dan Depresiasi Sumberdaya ikan Layang (discount rate 18\%)

\section{Analisis Model Dinamis}

Hasil simulasi berdasarkan model dinamis degradasi sumberdaya ikan layang di Kota Ambon menunjukkan bahwa terindikasi telah terjadi degradasi dan depresiasi terhadap sumberdaya ikan layang dengan rata-rata nilai koefisien degradasi dan depresiasi sebesar 0,28 persen dan 0,59 persen per tahun dari batas toleransi koefisien laju degradasi dan depresiasi yang ditetapkan sebesar 0,5 persen. Bernilai 0,28 persen dan 0,59 persen artinya kondisi ini menunjukkan bahwa setiap tahunnya sumberdaya ikan layang di Perairan Kota Ambon mengalami depresiasi akibat dari peningkatan produksi dan upaya tangkap setiap tahunnya tetapi belum terdegradasi, sehingga depresiasi terhadap produksi menunjukkan korelasi positif artinya bahwa tingkat eksploitasi sumberdaya ikan layang dengan laju depresiasi pada Gambar 6 diatas menunjukkan tren yang meningkat dimana ketika effort ditingkatkan dalam menghasilkan produksi maka akan menyebabkan degradasi maupun depresiasi terhadap sumberdaya ikan layang, sehingga dapat dikatakan bahwa laju degradasi 
dan laju depresiasi bersifat sensitif terhadap perubahan parameter biofisik dan ekonomi dari sumberdaya ikan layang di Perairan Kota Ambon.
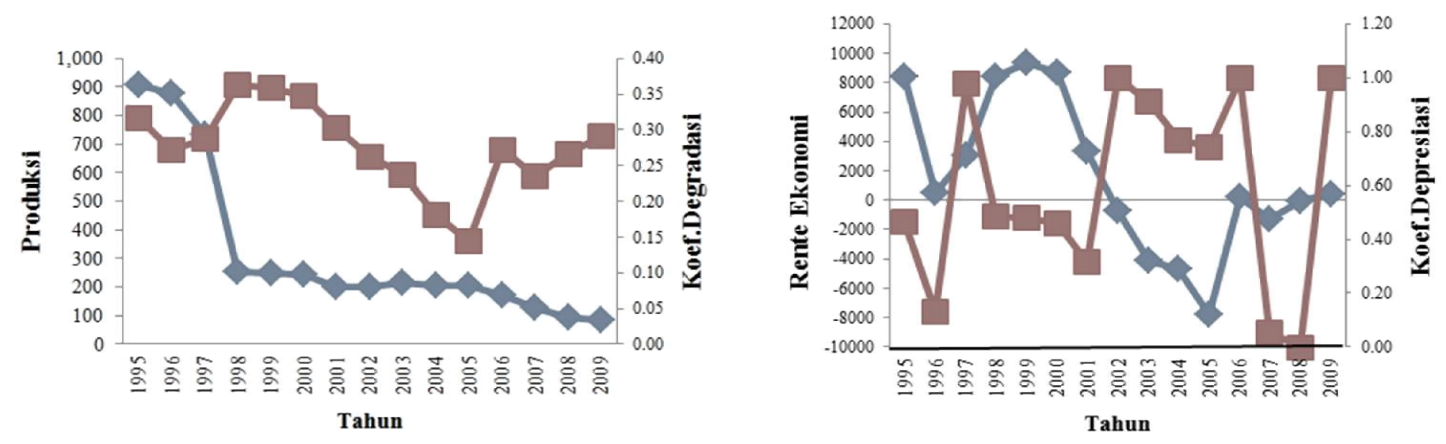

Gambar 7. Hasil Simulasi Model Dinamis Sumberdaya Ikan Layang

\section{Analisis Kesejahteraan Produsen}

Dengan menggunakan parameter biofisik dan ekonomi yang telah dihitung, maka diperoleh surplus produsen pada Tabel 7 kondisi baseline pada setiap tahunnya. Dari Tabel 7 yang disajikan tampak bahwa pada kondisi baseline menunjukkan tren penurunan surplus produsen setiap tahunnya berarti bahwa kesejahteraan nelayan ikan layang cenderung mengalami penurunan berkisar antara Rp.3,66 juta hingga Rp.1,66 juta per tahun atau ratarata sebesar Rp.1,79 juta per tahun, artinya surplus produsen untuk pemanfaatan sumberdaya ikan layang di Perairan Kota Ambon memiliki kecenderungan penurunan nilai setiap tahunnya, selanjutnya untuk mengetahui sejauh mana interaksi perikanan pada kondisi baseline berdampak pada kesejahteraan secara keseluruhan, dilakukan dengan perhitungan total benefit.

Tabel 7. Nilai Surplus Produsen untuk sumberdaya Ikan Layang

\begin{tabular}{ccccc}
\hline Tahun & $\begin{array}{c}\text { Harga } \\
(\mathrm{Rp})\end{array}$ & $\begin{array}{c}\text { Sustainable Yield } \\
\text { (ton) }\end{array}$ & $\begin{array}{c}\text { Biaya } \\
(\mathrm{Rp})\end{array}$ & $\begin{array}{c}\text { Surplus Produsen } \\
(\mathrm{Rp})\end{array}$ \\
\hline 1995 & 100,00 & 907,55 & 133,81 & 3,669 \\
1996 & 100,00 & 878,40 & 139,24 & 2,083 \\
1997 & 111,80 & 733,35 & 104,43 & 2,027 \\
1998 & 180,04 & 252,70 & 250,69 & 1,700 \\
1999 & 213,06 & 248,40 & 296,66 & 1,695 \\
2000 & 229,41 & 244,05 & 319,43 & 1,689 \\
2001 & 242,12 & 202,35 & 337,13 & 1,632 \\
2002 & 269,56 & 202,25 & 375,33 & 1,632 \\
2003 & 281,14 & 214,25 & 391,46 & 1,649 \\
2004 & 108,50 & 204,05 & 151,07 & 1,634 \\
2005 & 117,83 & 203,20 & 164,07 & 1,633 \\
2006 & 133,63 & 170,50 & 186,07 & 1,579 \\
2007 & 140,25 & 126,00 & 195,28 & 1,486 \\
2008 & 129,11 & 93,15 & 179,77 & 1,393 \\
2009 & 113,17 & 83,55 & 157,58 & 1,360 \\
\hline Rata-rata & 164,37 & 317,58 & 225,47 & 1,791 \\
\hline
\end{tabular}

Sumber: Data diolah, 2014.

Hasil analisis total benefit sumberdaya perikanan pada kondisi baseline dengan ratarata total benefit sebesar Rp.5,86 juta per tahun dari total benefit sebesar Rp.8,79 juta per tahun. Dengan demikian penurunan surplus produsen sebesar Rp.1,79 juta per tahun pada kondisi baseline merupakan suatu nilai yang signifikan bagi nelayan di Perairan Kota Ambon yang sebagian besar adalah nelayan tradisional dengan penghasilan yang relatif kecil dan dalam kondisi miskin. Dalam kondisi ini surplus produsen menggambarkan tingkat kegiatan penangkapan yang seharusnya cenderung terjadinya peningkatan tetapi terjadi 
penurunan terhadap surplus produsen dengan indikasi terjadi penurunan kesejahteraan dari tahun ke tahun, sesuai kenyataan kondisi nelayan di Perairan Kota Ambon secara nyata tingkat kesejahteraan nelayan sangat memprihatinkan dan tidak terjadi perbaikan kesejahteraan yang setiap tahunnya di Perairan Kota Ambon, maka kondisi social dan ekonomi nelayan akan sejahtera dan surplus produsen meningkat bilamana mengacu pada surplus produsen akan tercapai maksimal apabila pengelolaan sumberdaya dilakukan secara optimal.

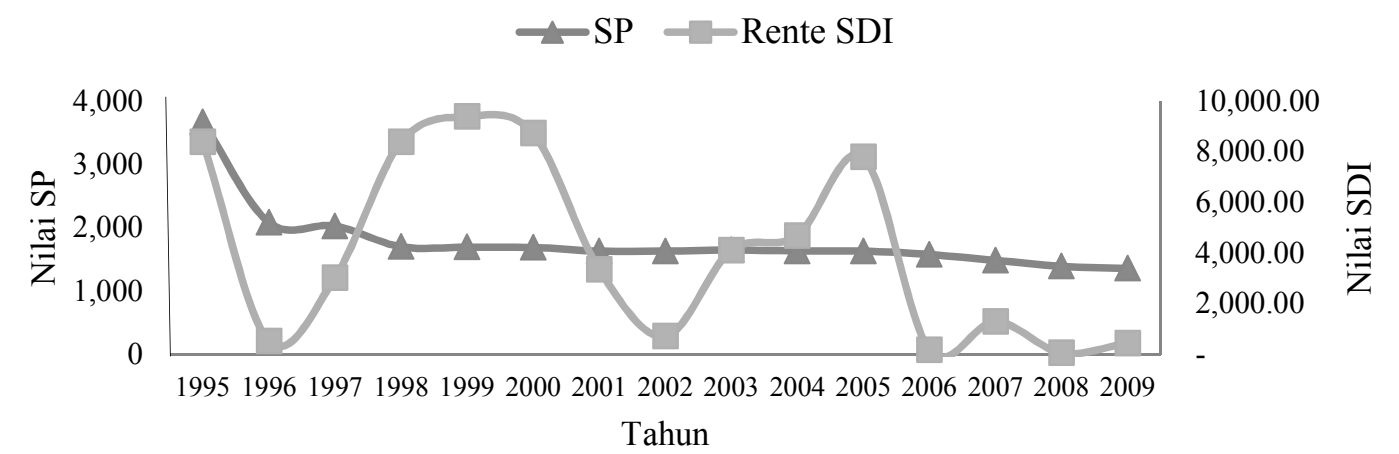

Gambar 8. Rente Ekonomi Aktual dan Surplus Produsen.

\section{Analisis Kebijakan}

Pengelolaan sumberdaya ikan layang di Perairan Kota Ambon merupakan suatu proses yang sangat kompleks karena banyak pihak yang terkait terhadap sumberdaya perikanan tersebut. Untuk mencapai pengelolaan yang berkelanjutan dan lestari harus mengakomodir kepentingan sebagian besar pihak yang terkait seperti stakeholder, LSM, dan masyarakat nelayan, dalam menentukan kebijakan pengelolaan sehingga diperoleh keputusan yang tepat dan dapat diterima banyak pihak yang saling terkait. Analisis kebijakan dilakukan dengan pendekatan Analisis Hierarki Proses (AHP) yaitu pada susunan hierarkinya.

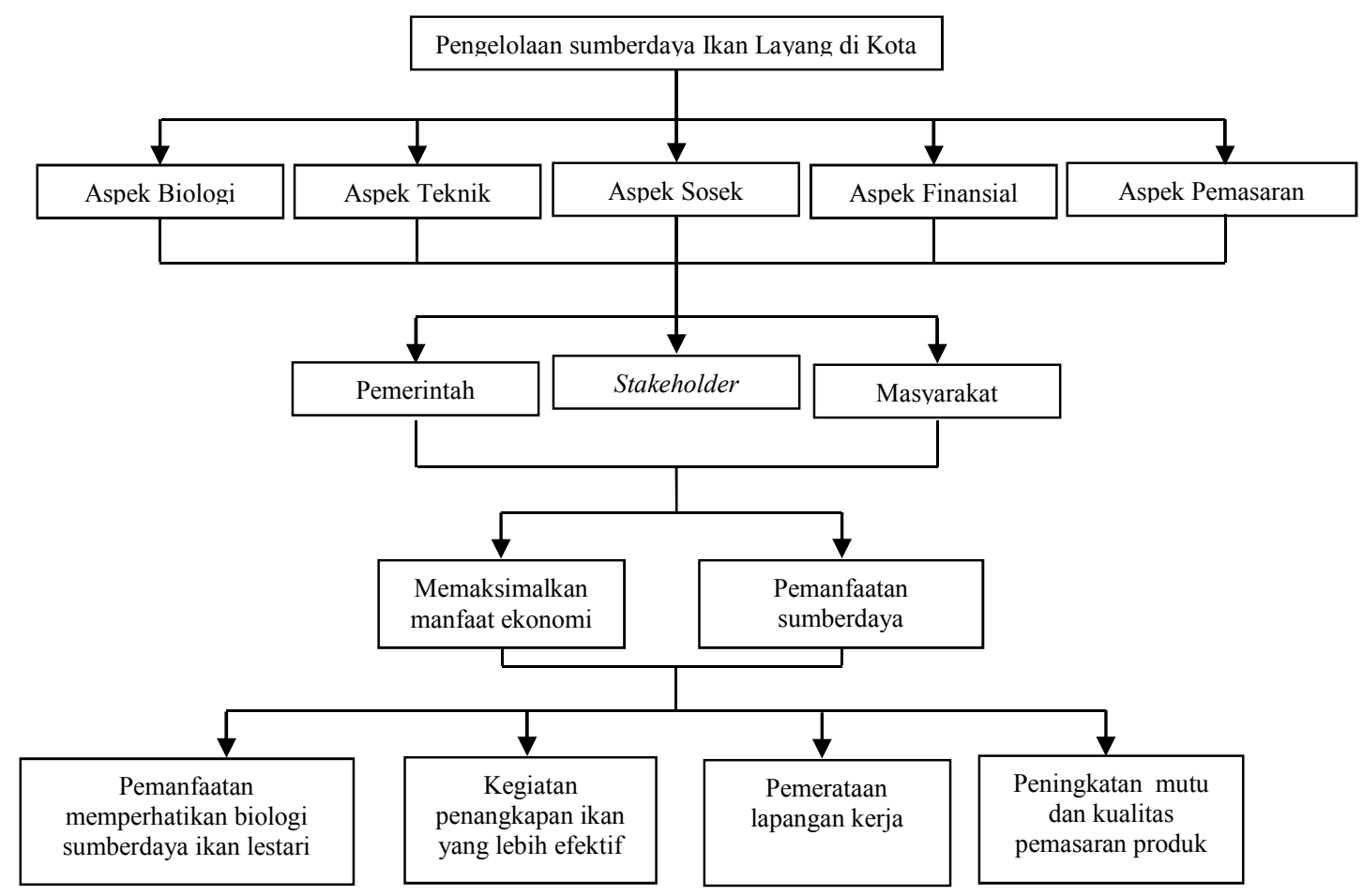

Gambar 9. Hierarki Pengelolaan SDI layang di Kota Ambon 
Tujuan utama dari pengambilan keputusan ini yaitu terbentuknya pengelolaan sumberdaya ikan layang berkelanjutan. Pada tingkat pertama tujuan yang digunakan adalah pengelolaan sumberdaya ikan layang di Perairan Kota Ambon. Pada tingkat kedua, kriteria yang digunakan antara lain: (1) aspek biologi, (2) aspek teknik, (3) aspek sosial ekonomi, (4) aspek finansial, (5) aspek mutu dan pemasaran. Pada tingkat ketiga merupakan pihak-pihak yang terkait yang dipilih antara lain: (1) Pemerintah/PEMDA, (2) Stakeholder, (3) masyarakat nelayan. Pada tingkat keempat sub kriteria antara lain: (1) Maksimalkan manfaat ekonomi, (2) pemanfaatan sumberdaya perikanan berkelanjutan. Pada tingkat kelima merupakan pilihan maka yang dipilih antara lain: (1) pemenfaatan memperhatikan biologi sumberdaya ikan lestari, (2) kegiatan penangkapan ikan yang lebih efektif, (3) pemerataan lapangan kerja, (4) peningkatan mutu dan kualitas pemasaran.

\section{Persepsi Pihak-Pihak dalam Pengelolaan Sumberdaya Ikan Layang di Kota Ambon}

Hasil analisis terhadap persepsi pihak-pihak yang terkait dalam pengelolaan sumberdaya ikan layang di Perairan Kota Ambon secara berkelanjutan dengan menggunakan Analisis Hierarki Proses (AHP), pada tingkat pertama diperoleh vektor prioritas dari pihakpihak yang berperan dan berkepentingan dengan nilai yang diperoleh untuk masing-masing pihak yang saling terkait adalah: pemerintah $(0,503)$, stakeholder $(0,268)$, dan masyarakat nelayan $(0,230)$, dari penilaian tersebut diperoleh bahwa kriteria yang paling tinggi nilainya adalah pemerintah dalam hal ini PEMDA, hal ini berarti bahwa dalam pengelolaan sumberdaya ikan layang berkelanjutan yang berperan penting adalah pemerintah Tabel 8 .

Tabel 8. Penilaian Kebijakan Pengelolaan SDI Layang di Perairan Kota Ambon

\begin{tabular}{clc}
\hline No & \multicolumn{1}{c}{ Aktor } & Skor \\
\hline 1 & Pemerintah & 0,503 \\
2 & Stakeholder & 0,268 \\
3 & Masyarakat Nelayan & 0,230 \\
\hline
\end{tabular}

Sumber: Data diolah, 2014.

Pemerintah sebagai pemegang kekuasaan utama dalam pengelolaan sumberdaya ikan layang dalam melaksanakan suatu kebijakan harus melibatkan masyarakat nelayan dan stakeholder dalam pengambilan suatu keputusan sebagai proses dari pengelolaan sumberdaya ikan layang di Perairan Kota Ambon sehingga dalam menghasilkan suatu keputusan tentang prngelolaan sumberdaya ikan layang berkelanjutan di Perairan Kota Ambon akan tercapai dengan baik.

\section{Persepsi Terhadap Beberapa Aspek Pengelolaan Sumberdaya Ikan Layang di Kota Ambon}

Hasil analisis terhadap beberapa aspek pengelolaan sumberdaya ikan layang yang saling terkait, dengan nilai yang didapat pada masing-masing kriteria adalah: aspek biologi $(0,419)$, aspek teknik $(0,251)$, aspek sosial ekonomi $(0,171)$, aspek finansial $(0,095)$, dan aspek mutu dan pemasaran $(0,65)$. Lebih jelas penilaian terhadap beberapa aspek terkait disajikan pada Tabel 9. Dimana terlihat nilai yang tertinggi adalah aspek biologi kemudian aspek teknik, aspek sosial ekonomi, aspek finansial dan aspek mutu dan pemasaran.

Tabel 9. Penilaian Kebijakan Aspek Pengelolaan SDI Layang di Kota Ambon

\begin{tabular}{clc}
\hline No & \multicolumn{1}{c}{ Aspek pengelolaan SDI layang } & Skor \\
\hline 1 & Biologi & 0,419 \\
2 & Teknik & 0,251 \\
3 & Sosial dan ekonomi & 0,171 \\
4 & Finansial & 0,095 \\
5 & Mutu dan pemasaran & 0,065 \\
\hline
\end{tabular}

Sumber: Data diolah, 2014. 
Hal tersebut menjelaskan bahwa dalam pengelolaan sumberdaya ikan layang di Perairan Kota Ambon didasarkan pada hal utama yaitu ketersediaan sumberdaya ikan layang itu sendiri artinya bahwa jika potensi ikan layang memadai maka akan berdampak pada semua aspek terutama bagi usaha penangkapan ikan. Tabel 9 menunjukkan bahwa aspek biologi yang didalamnya termasuk kondisi stok ikan merupakan hal yang sangat penting dalam perikanan tangkap. Ketersediaan stok sumberdaya ikan layang yang mencukupi dan bermanfaat bagi berbagai pihak, namun demikian kondisi di lapangan menunjukkan bahwa sering kali sumberdaya ikan ini kurang diperhatikan dengan baik terutama oleh nelayan, dengan persepsi mereka bahwa untuk mencukupi kebutuhan hidup maka sumberdaya ikan yang ada harus dimanfaatkan tanpa batas tanpa harus memperhatikan stok dari sumberdaya tersebut. Hal lain juga terlihat dilapangan yakni terdapat daerah yang menjaga sumberdayanya dengan memberlakukan sistem sasi (konservasi tradisional berbasis masyarakat) dilakukan agar sumberdaya tertap terjaga sepanjang masa dan dapat dinikmati oleh generasi berikutnya.

\section{Persepsi terhadap komponen aspek pengelolaan sumberdaya ikan layang di Kota} Ambon.

Hasil analisis terhadap komponen aspek pengelolaan sumberdaya ikan layang yang terkait nilai yang didapat pada masing-masing sub kriteria adalah : pemanfaatan sumberdaya berkelanjutan $(0,729)$, memaksimalkan manfaat ekonomi $(0,271)$, terlihat nilai tertinggi ditunjukan oleh sub kriteria pemanfaatan sumberdaya berkelanjutan. Hal ini menjelaskan bahwa akibat dari tingginya aktifitas penangkapan maka perlu adanya pemanfaatan yang memperhatikan keberlanjutan dari sumberdaya tersebut. Untuk lebih jelasnya hasil penilaian untuk komponen dari aspek terkait dapat dilihat pada Tabel 10 berikut:

Tabel 10. Penilaian Komponen Aspek Terkait Pengelolaan SDI Layang di Kota Ambon

\begin{tabular}{clc}
\hline No & \multicolumn{1}{c}{ Komponen pengelolaan SDI layang } & Skor \\
\hline 1 & Memaksimalkan manfaat ekonomi & 0,271 \\
2 & Pemanfaatan sumberdaya berkelanjutan & 0,729 \\
\hline
\end{tabular}

Sumber: Data diolah, 2014.

\section{Pilihan Terhadap Beberapa Komponen Terpilih dalam Pengelolaan Sumberdaya Ikan Layang}

Penentuan pengelolaan sumberdaya ikan layang di Perairan Kota Ambon dianalisis berdasarkan pertimbangan pada tingkatan dari hierarki. Berdasarkan pertimbangan secara keseluruhan, diperoleh nilai vektor prioritasnya adalah : pemanfaatan memperhatikan biologi sumberdaya ikan lestari $(0,538)$, peningkatan mutu dan kualitas pemasaran produk $(0,161)$, penangkapan ikan yang lebih efektif $(0,152)$, dan pemerataan lapangan kerja urutan keempat dengan nilai $(0,148)$. Untuk lebih jelasnya hasil penilaian dapat dilihat pada Tabel 11 berikut:

Tabel 11. Penilaian Komponen Terpilih Pengelolaan SDI Layang di Perairan Kota Ambon

\begin{tabular}{clc}
\hline No & \multicolumn{1}{c}{ Aspek pengelolaan SDI layang } & Skor \\
\hline 1 & Pemanfaatan memperhatikan SDI lestari & 0,538 \\
2 & Peningkatan mutu dan kualitas pemasaran produk & 0,161 \\
3 & Penangkapan ikan yang lebih efektif & 0,152 \\
4 & Pemerataan lapangan kerja & 0,148 \\
\hline
\end{tabular}

Sumber: Data diolah, 2014.

Hasil akhir dari analisis digunakan untuk pengelolaan berkelanjutan terhadap stok dari sumberdaya ikan layang agar tetap terjaga kelestariaanya, dengan melakukan pembatasan terhadap penangkapan sumberdaya ikan layang di Perairan Kota Ambon sehingga prioritas utama aspek biologi terhadap stok sumberdaya ikan tetap lestari dan berkelanjutan. 


\section{SIMPULAN DAN SARAN}

\section{Simpulan}

Berdasarkan hasil penelitian yang telah dilakukan diperoleh beberapa kesimpulan dari pemanfaatan sumberdaya ikan layang di Perairan Kota Ambon sebagai berikut:

1. Pemanfaatan sumberdaya ikan layang (scad fish) di Perairan Kota Ambon terindikasi telah mengalami lebih tangkap secara biologi (biological overfishing) dan secara ekonomi (economic overfishing) maka diperlukan optimasi pengelolaan sumberdaya melalui penurunan effort penangkapan dari 192,318 trip per tahun menjadi 24,56 trip per tahun sehingga dapat memperoleh rente ekonomi optimal sebesar Rp.10,78 juta.

2. Sumberdaya ikan layang (scads fish) di Perairan Kota Ambon terindikasi mengalami degradasi dan depresiasi dengan rata-rata nilai nilai koefisien degradasi sebesar 0,28 dan nilai koefisien depresiasi sebesar 0,59 sudah melebuhi batas nilai toleransi 0,50 persen, akan tetapi belum terjadi degradasi secara keseluruhan. Apabila effort ditingkatkan maka nilai koefisien degradasi dan depresiasi akan meningkat dan sebaliknya ketika effort dikurangi maka nilai koefisien degradasi depresiasi akan semakin kecil hal ini sangat berpengaruh terhadap nilai depresiasi dan nilai depresiasi dari sumberdaya ikan layang di Perairan Kota Ambon.

3. Perubahan nilai depresiasi sumberdaya ikan layang (scads fish) tahun 1995 hingga 2009 dengan tingkat discount rate 05,65 persen memperlihatkan depresiasi terjadi pada tahun 1996, 1997, 2004, 2006, 2007,2008, dan 2009 sedangkan kondisi perbaikan (recovery) terjadi tahun 1995, 1998, 1999, 2000, 2001, 2002, 2003, 2005 telah melebihi batas nilai toleransi koefisien degradasi dan depresiasi sebesar 0,50 persen.

4. Model dinamis degradasi dan depresiasi yang dibangun mengindikasikan bahwa terjadi depresiasi terhadap sumberdaya ikan layang (scads fish) di Perairan Kota Ambon tetapi belum terjadi degradasi karena nilai koefisien degradasi masih dibawah batas nilai koefisien toleransi 0,5 persen kondisi ini menunjukkan bahwa setiap tahunnya sumberdaya ikan layang di Perairan Kota Ambon mengalami degradasi dan depresiasi dengan rata-rata peningkatan upaya tangkap, produksi maupun keuntungan yang diperoleh setiap tahunnya.

5. Rata-rata nilai surplus produsen menunjukkan penurunan setiap tahunnya berarti bahwa bahwa kesejahteraan nelayan ikan layang cenderung mengalami penurunan berkisar antara Rp.3,66 juta hingga Rp.1,66 juta per tahun atau rata-rata sebesar Rp.1,79 juta per tahun.

6. Kebijakan pengelolaan sumberdaya ikan layang (scads fish) menunjukkan bahwa Aspek Biologi Ikan memiliki skor tertinggi $(0,419)$, aktor yang memiliki skor tertinggi adalah Pemerintah $(0,503)$, selanjutnya prioritas utama yang memiliki skor tertinggi adalah Pemanfaatan Sumberdaya Perikanan berkelanjutan sebesar $(0,729)$ dan alternatif Pemanfaatan Memperhatikan Aspek Biologi dari Sumberdaya Ikan dengan skor $(0,538)$ hasil ini digunakan sebagai rujukan/prioritas utama dalam perencanaan kebijakan pengelolaan berkelanjutan sumberdaya ikan di Perairan Kota Ambon.

\section{Saran}

Dari penelitian yang telah diakukan ini maka disarankan:

1. Perlunya memberlakukan pembatasan upaya tangkap baik terhadap unit alat tangkap maupun ukuran mata jarring dalam eksploitasi sumberdaya ikan di Perairan Kota Ambon.

2. Pemerintah seharusnya dapat mengatur kegiatan exploitasi terhadap sumberdaya ikan layang (scads fish) dalam pengelolaan berkelanjutan karena memiliki tingkat kepentingan dan pengaruh yang tinggi jika dibandingkan dengan pihak-pihak yang lain.

\section{DAFTAR PUSTAKA}


Anderson LG. 2010. Bioeconomics of Fisheries Management. USA: Newark Delaware.

Anna, S. 2003. Model Embedded Dinamik Ekonomi Interaksi Perikanan Pencemaran [disertasi] Bogor (ID). Institut Pertanian Bogor.

Arifin,F. 2008. Optimasi Perikanan Layang di Kabupaten Selayar Provinsi Sulawesi Selatan [tesis]. Bogor (ID): Institut Pertanian Bogor.

Atmajaya,S.B. dan Nugroho, D. 2005. Aplikasi Model Beverton dan Holt bagi Ikan Layang (Decapterus spp) di Laut Natuna dan sekitarnya. [jurnal] Penelitian Perikanan.

[BPS] Badan Pusat Statistik, 2003. Pendapatan Regional Kota Ambon Tahun 2002. Ambon (ID): Badan Pusat Statistik Kota Ambon.

Brandt, A. von. 1984. Fish Catching Methods of The World. 3rd Edition. Warwickshire: Avon Litho Ltd., Stratford-upon-Avon.

Charles A. 2001. Sustainable Fishery Systems. Canada: Blackwell Science Ltd.

[DKP] Dinas Perikanan dan Kelautan Kota Ambon, 2003. Profil Sumber Daya Perikanan dan Kelautan Kota Ambon. Ambon (ID): Dinas Perikanan dan Kelautan Kota Ambon.

Eriyatno. 1999. Ilmu Sistem: Meningkatkan Mutu dan Efektifitas Manajemen. Bogor (ID): IPB Press.

Fauzi, A, 2004. Ekonomi Sumberdaya Alam dan Lingkungan (Teori dan Aplikasi). Jakarta (ID): Gramedia.

2005. Kebijakan Perikanan dan Kalautan. Bogor (ID): Grafika Mardiyuana.

.2010. Ekonomi Perikanan: Teori, Kebijakan dan Pengelolaan. Jakarta (ID): Gramedia.

Fauzi, A dan Anna, S. 2005. Pemodelan Sumberdaya Perikanan dan Kelautan. Jakarta (ID): Gramedia.

Kuncoro, M., 2001. Metode Kuantitatif (Teori dan Aplikasi Untuk Bisnis dan Ekonomi). Yogyakarta (ID): AMP YKPN.

Marimin. 2005. Teknik dan Aplikasi Sistem Pakar Dalam Teknologi Manajerial. Bogor ID): IPB Press.

Marimin. Nurul M. 2010. Aplikasi Teknik Pengambilan Keputusan dalam Manajemen Rantai Pasok. Bogor (ID): IPB-Press.

Muhammadi. et. al. 2001. Analisis Sistem Dinamis: Lingkungan Hidup, Sosial Ekonomi dan Manajemen. Jakarta (ID): UMJ Press.

Nabunome, W. 2007. Model Analisis Bioekonomi dan Pengelolaan Sumberdaya Ikan Demersal di Kota Tegal [tesis]. Semarang (ID): UNDIP.

Nasir, M. 1988. Metode Penelitian. Jakarta (ID): Ghalia Indonesia.

Prihartini, A. 2006. Analisis Tampilan Biologis Ikan Layang Hasil Tangkapan Purse Seine Yang Di Daratkan Di PPN Pekalongan [tesis]. Semarang (ID): UNDIP

Ralahalu, K. A., 2007. Pembangunan Daerah Kepulauan dan Visi Maluku 2030. Pemerintah Provinsi Maluku dan Indonesia Media Otda (IMO), Jakarta.

Sangadji, A., S. 2008. Perikanan/Kelautan Maluku Nasibmu Kini. [internet] [diunduh] [19 Januari 2013]. Tersedia pada: http://www.michr.net.

Saaty TL.1983. Decision Making For Leaders: The Analytical Hierarchy Process For Decision In Complex World. Pittsburgh. RWS Publication.

Sevilla CG, Ochave JA, Punsalan TG, Regala BP, Uriarte GG. 1993. Pengantar Metode Penelitian. Alimuddin Tuwu, penerjemah. Jakarta (ID): UI Press.

Sobari MP, Diniah dan Isnaini. 2009. Kajian Bio-ekonomi dan Investasi Optimal Pemanfaatan Sumberdaya Ikan Ekor Kuning di Perairan Kepulauan Seribu. Jurnal Magrove dan Pesisir.

Sutriono, Hanafie SR. 2007. Filsafat Ilmu dan Metodologi Penelitian. Yogyakarta (ID): CV Andi Offset.

Zulbainarni N. 2012. Pemodelan Bioekonomi dalam Pengelolaan Perikanan Tangkap. IPB Press. Bogor. 